\title{
Industrial Gardening-A Review
}

\author{
Snehasis Dalal, Balusu Dhanunjaya, Vishwjeet, Reshma Chongtham, \\ Parul Sharma and Homraj Sahare*
}

School of Agriculture, Lovely Professional University, Jalandhar-Delhi G. T. Road,
Phagwara, (Punjab), India

*Corresponding author

\section{A B S T R A C T}

\section{Keyw ords \\ Ample, Dust, Hostile, Shade, Vacant}

Article Info

Accepted: 12 October 2020 Available Online: 10 November 2020
Industrial garden is a new approach, especially for competition in increasing pollution in the atmosphere. It helps easily to beautify the industrial areas. The lawn laid in vacant lands not only adds beauty but also cut down dust. These gardens are designed to reduce pollution and beautify the world. These units are the most sources of air, water, noise and soil pollution. Another important aim is to provide ample amount of shade and coolness so that the workers get a sigh of relief under the trees from the hostile hot interior of the industry as trees can brings down the temperature around the industry considerably.

\section{Introduction}

Beautification of factories and industrial townships to form a much better surrounding for living operating, recreation, and circulation square measure the objectives of landscape planners. Garden construction and style was the start of what was called "landscape architecture". The world's oldest gardening is forest gardening ${ }^{[4]}$.It was begun in West Asia and unfold westward into what's Europe these days. The word, "garden" came from the English word, "geard", which meant "enclosure". Education may be a powerful resolution to today's issues, and gardens may simply be the solution. People have become more educated in terms of computer and technology specifically, that square measure permitting them to own additional free time throughout this pandemic. In Hyderabad a densely inhabited industrial areas are departure residents susceptible to pollutants. As a significant a part of town was engulfed in air pollution and a chemical-like smell for the previous couple of years, urban designing consultants urged a rethink on the placement of industries.

"Areas that were earlier deserted around industrial areas together with Miyapur, Nacharamar currently residential hubs. In the 70s, paddy was still being fully grown there, 
however with the agitated development, the density of town has undergone a huge amendment," Former human of the Indian Institute of Chemical Technology (IICT) same there's a desire for caution as usually industrial areas should have a buffer zone to guard the common person WHO might not remember of the impact of emissions and doable leaks from industries - significantly chemical industries placed within the town and its surroundings.

As a result, the world's population has additional time off. Why not get into native inexperienced areas and gardens? Why not manufacture additional gardens of each kind and visit those that square measure already created close whereas maintaining social distancing.

\section{History}

In $27 \mathrm{BC}$, a Roman author and engineer by the name of Vitruvius wrote a book known as, "Ten Books on Architecture". He talked about concerning style, landscape, engineering the surroundings, water, and also the importance of personal gardens. He introduced concepts like beauty, convenience, and utility. Throughout history, agriculture has been in constant development.

The traditional decorative garden evolved into the medieval vegetable plot established within the former marsh areas of Paris. Within the nineteenth century, scientific innovations improved techniques and tools that paved the method for industrial agriculture.

The industrial revolution of $19^{\text {th }}$ century, marked a turning purpose for industrial agriculture. Mechanization extended to each agricultural tools and growing techniques. In chemistry, the invention of the importance of phosphoric and chemical elements for the expansion of plants light-emitting diode to the assembly of artificial fertilizers and therefore improved intensive farming. The invention of the external-combustion engine, followed by that of the combustion engine results in the event of transport networks that 'reduced' the gap between urban and agricultural areas.

Crops stirred removed from the cities and into rural areas with additional appropriate growing conditions. Personal allotment gardens developed inside cities and provided recent fruit and vegetables for subsistence functions (Table 1).

\section{Scope}

For a landscape designer, there is ample scope to implement its aesthetic concepts in such units.

Different square measures are to be improved by providing streets, sidewalks, sewers and sanitation, installation of public utilities like water, electricity, gas and different conveniences.

Between the industrial plant and district, inexperienced belts may even be created by planting trees.

To maintain ecological imbalance

\section{Industrial gardening}

The goal is to spot different markets that are currently either underserved with creativity about growing plants or perhaps are unaware that there are different solutions to solving today's emerging challenges in controlled environment agriculture.

Gardening in and around factories are needed to fight pollution besides beautification. Open spaces around the buildings can be utilised for plantations and gardening to minimise the ecological imbalance. It also works as therapeutic. It's the best way to relieve stress. Having your own green space and sitting 
amongst fragrant plants can boost your mood! Sipping a cup of your favourite beverage and sitting in your area filled with plants will ease your mind and calm your nerves. Plants are therapeutic and are scientifically proven to alleviate anxiety and stress.

Explore new and better ways to regulate every aspect of growing and gardening-moisture, temperature, airflow, different atmosphere needs, and lots of other factors that will impact total production.

Planting is completed within the industrial gardens to reduce the amount of dust and chops down the noise. They reduce the amount of carbon dioxide in the air, and increase oxygen and they help eliminate toxins from smoke that emits from industries $^{[8] \text {. }}$

A large number of such trees are planted, either in groups, clumps or in multiple rows which can enhance beauty, provide shade and regulate the environment for peaceful conversations. A device that took my attention was The 'Phyto-sensor' toolkit, developed by the Citizen Sense research group that is led by Goldsmiths sociologist.

This device provides timely recommendation for vegetation to mitigate and monitor waste levels. This is often a citizen's toolkit for planting air quality gardens. The toolkit includes directions for distinctive the most effective locations for air quality gardens, also as totally different planting ways and maintenance techniques ${ }^{[1]}$.

\section{Buffer zone}

\section{Experts say industrial areas must have buffer zone}

A buffer zone is an area that was created in the pollution affected area, mainly air and noise pollution. It is an area of green network that covers parking lots, vehicle access, pedestrian walkways and areas for tree planting, landscaping and biome. There are varied styles of buffer zone like recreational parks and barrier walls.

A buffer zone ought to be supplied with a distance of thirty meters to crop band special and serious business, twenty meters to ten meters medium business to light-weight business ${ }^{[6]}$.

\section{Case studies}

1. 'The factory in a Garden' that traces the history of the commercial gardens movement from its late-eighteenthcentury beginnings in Great Britain to its ordinal century equivalent in Google's vegetable gardens at their headquarters in CA. The book was the 1st study of its kind examining the event of parks, gardens, and outside leisure facilities for industries in Great Britain and America as a model for the reshaping of the company setting within the ordinal century. This was additionally the primary book to relinquish a comprehensive account of the contribution of gardens, agriculture, and recreation to the history of accountable market economy and moral operating practices $^{[7] \text {. }}$

2. A journal by Richard Thompson in June 2018 cited that health professionals ought to encourage the public to create use of the unutilised area and may pressure native authorities to extend open areas and therefore plant variety of trees, so additionally serving to counteract pollution and global climate change ${ }^{[2] \text {. }}$

3. A study in April 2014 reviews the benefits of farming and community food growing for every physical condition. Benefits of business farming for condition and wellbeing includes gardens, still as a result of 
the activity of farming, shown to possess a positive impact on peoples' health and well-being, the results of every physical activity and so the utilization of the garden as a mental relaxation and stimulation. Gardeners appear to recollect that farming is good for his or her mental health. An interview of 144gardeners, found that recreation $(21 \%)$ was the foremost necessary reason followed by health edges in addition to mental health (19\%), physical health and exercise (17\%) and produce quality and nutrition (14\%). Besides the activity of farming, viewing the inexperienced house and being in an inexperienced house has collectively been shown to possess positive effects on condition and stress ${ }^{[3] \text {. }}$

4. Another study by J. Community Health in August 2012 primarily delineates the impact of a community farming project on vegetable intake, food security, and family relationships. Thirty-eight families listed within the study throughout the pregarden fundamental measure, and 125 families added to the list later for the study of post-garden. Of the families listed throughout the pre-gardening fundamental measure, there have been 163 house members.

5. The mean age of the answerer was 44, starting from 21 to 78 years getting on. This study was vital as a result of it succeeded in enrolling and following thirty eight underserved families UN agency actively participated within the organic community farming project over 2 growing seasons. Their findings indicate that the community farming project controls several health edges yet as ornamental purposes. Additionally, several families expressed satisfaction with knowing the vegetables they grew in their gardens were chemical-free, the method of getting a garden carried on traditions they learned from the family in Mexico, and therefore the economic edges of not having to pay cash on food. In conclusion, they learned from this study that a community farming program will cut back food insecurity, improve vegetable intake, and strengthen family relationships with some aesthetic garden styles $^{[9]}$.

6. Thomas Pugh explained that concentrations of nitrogen dioxide (NO2) and microscopic particulate matter (PM) - both of which can be harmful to human health exceeds safe levels on the streets of many cities. Past analysis advice that trees and other green plants can improve urban air quality by removing those pollutants from the air.

7. However, the improvement seemed to be as small as less than 5 percent. The new study provide a better understanding of the effects of green plants in stagnant air of city streets, which the authors term "urban street canyons." The study concluded that judicious placement of grass, ivy and other plants in urban canyons can reduce the concentration at street level of NO2 by as much as $40 \%$ and PM by $60 \%$, much more than previously believed. $\mathrm{T}$

8. he authors even suggested that building plant-covered "green billboards" in these urban canyons to increase the amount of foliage. Trees were also shown to be effective, but only if care is taken to avoid trapping pollutants beneath their crowns ${ }^{[5]}$. 
Table.1

\begin{tabular}{|c|c|}
\hline \multicolumn{2}{|c|}{ Trees recommended for Industrial Gardening } \\
\hline Scientific Name & Common Name \\
\hline Corymbiacitriodora & Lemon-scented gum \\
\hline Ficusreligiosa & Pipal \\
\hline Ficusbenjamina & Weeping fig \\
\hline Ficusreligiosa & Sacred fig \\
\hline Cynarascolymus & Artichokes \\
\hline Bougainvillea spp & Bougainvillea \\
\hline Betulapendula & European birch \\
\hline Ginkgobiloba & Ginkgo \\
\hline Koelreuteriapaniculata & Golden raintree \\
\hline Tiliacordata & Littleleaf linden \\
\hline Acer spp & Maple \\
\hline Quercusrubra & Red oak \\
\hline Pyrus spp & Pear \\
\hline Magnoliagrandiflora & Southern magnolia \\
\hline Liriodendrontulipifera & Tulip tree \\
\hline \multicolumn{2}{|c|}{ Edible plants recommended for Industrial Gardening } \\
\hline Apple & Persimmon \\
\hline Pear & Huckleberries \\
\hline Citrus & Strawberry \\
\hline Plum & Kiwi \\
\hline Figs & Grape \\
\hline Loquats & Guava \\
\hline Peach & Blueberry \\
\hline
\end{tabular}

Fig.1

\section{REASONS FOR CONCERN}

$$
\square 0=10 \quad 20 \square 30 \square 40 \square 50 \square 60
$$

AASTHAMA AND BREATHLESSNESS

TB AND LUNG INFECTION

GENERAL HEALTH PROBLEMS

SKIN INFECTION

EYE INFECTION

CANCER
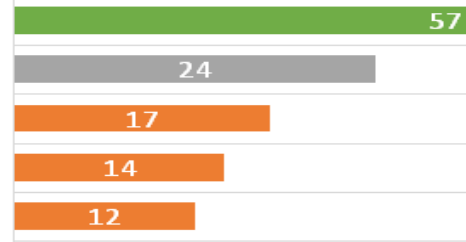

12

IMPACT ON WEATHER

GLOBALWARMING

NORESPONSE

DECREASE IN LIFE SPAN

Asthma is the leading health problem faced by most of the Indians. It accounts for more than $50 \%$ health problems caused by air pollution 
The factories could also be loosely classified into two

The first cluster contains relatively neat factories sort of a fruit process plant that emit less dirt and different polluting material.

The second cluster consists of factories like cement, steel, plant food etc., that emit heaps of dirt, smoke and harmful chemicals.

\section{Advantages}

Another vital aim of business garden is to produce ample shade and coolness so as that the employee gets a respite beneath the coolness of trees from the hostile hot interior of the industrial plant.

If set opted with acceptable plan, the trees bring down the temperature inside the industrial plant premises to a considerable extent.

In massive industrial plant a buffer zone may even be created by conversion between the industrial plant and its residential colony.

An industrial plant space can also be beautified with rockeries, statues, water pools, lakes or fountSains.

Bougainvillea square measure typically used freely to beautify the industrial plant space as these vibrant flowers can bring life to drab landscape of industrial plant space.

Hardy shrubs additionally play a vital role in beautifying factories once planted in shrubberies.

Lawns arranged in vacant lands not solely add beauty however additionally hamper dirt.

Gardens square measure typically arranged inside the industrial plant earlier than a canteen, rest-shed, hospital administration building then on.

\section{Disadvantages}

Some of the potential challenges of beginning a farming business include:
You can have some huge competitors, together with stores like Home Depot and different massive farming firms.

You can would like exceptional information of farming.

You can would like in depth information of organic materials, products, pesticides, etc.

You may have business and tax licenses, also as certifications.

Your business could prevent if you reside in a very seasonal climate.

In conclusions the study suggested that industrial gardens were perceived by gardeners to provide numerous benefits, including improved access to food, increased physical activity and improved mental health. Industrial gardens were also seen to promote social health benefits and social connections. There is a dire need of gardens, as the world is heading towards the depletion of natural resources due to urbanization. All the open areas are eaten away by household complex and industries. This has created the ecological imbalance, which can cause tremendous harm to the future generations. When we cannot avoid utilizing open spaces for the development of industries, then a minimum number of open spaces available around these buildings can be utilized for plantations and gardens to minimize the ecological imbalance, here the industrial gardening steps in.

There are many benefits of these industrial gardens, such as waste recycling, ecological benefits, energy conservation, water conservation, decorative enhancement of buildings, health benefits and attracting birds and insects.

\section{References}

1. Thomas AM, Robert A, MacKenzie J, Duncan Wand Nicholas H. (2012). The Effectiveness of Green Infrastructure for 
Improvement of Air Quality in Urban Street Canyons. Environmental Science \& Technology. 6(14): 7692-7699.

2. Carney PA, Hamada J L, Rdeniski R, Sprager L, Nikolas K R. (2013). Impact of a Community Gardening Project on Vegetable Intake, Food Security and Family Relationships: A Community-based Participatory Research Study. Journal of community health. 37 (4): 874-881.

3. Chance H. (2010). The Factory in a Garden: A History of Corporate Landscapes from the Industrial to the Digital Age. Manchester University Press, February 2017.

4. McConnell, O J. (2003), The forest Farms of kandy and other gardes of complete design p.1 ISBN9780754609582.

5. Citizen S. (2018). How to grow your own air quality garden. Museum of London $p$.
$1-88$.

6. Rahim (2014). Implementation of buffer zone in industrial area. IEEE Colloquium on Humanities, Science and Engineering. p. 72-78.

7. Schmutz (2014). The benefits of gardening and food growing for health and wellbeing. Garden Organic and Sustain Ulrich Schmutz, Margi Lennartsson, Sarah Williams, Maria Devereaux and Gareth Davies p.1-47.

8. Smith. (2018). A guide to building an 'air quality garden', detailing which plants are best equipped to combat harmful pollutants. Goldsmths, University of London P.1-2.

9. Thompson R. (2018). Gardening for health: a regular dose of gardening. Clinical Medicine. 18(3): 201-205.

\section{How to cite this article:}

Snehasis Dalal, Balusu Dhanunjaya, Vishwjeet, Reshma Chongtham, Parul Sharma and Homraj Sahare. 2020. Industrial Gardening-A Review. Int.J.Curr.Microbiol.App.Sci. 9(11): 1667-1673. doi: https://doi.org/10.20546/ijcmas.2020.911.198 